\title{
THE ANALYSIS OF MALARIA DISEASE DETERMINANTS IN LANGKAT, NORTH SUMATERA
}

\author{
Rahmadani Sitepu'), Mayang Sari Ayu(1), Alamsyah Lukito1), \\ Elaninanivi br T2) \\ 1)Department of Public Health, Faculty of Medicine, \\ Universitas Islam Sumatera Utara \\ ${ }^{2)}$ Masters Program in Health, Faculty of Medicine, \\ Universitas Sumatera Utara
}

\begin{abstract}
Background: Malaria is a disease caused by protozoal infection of the Plasmodium genus. The disease is transmitted through the bite of Anopheles female mosquito and breeds in human red blood cells. Malaria is found almost all over the world, especially in tropical and sub-tropical countries. This study aimed to analyze the risk factors of malaria incidence in Langkat, North Sumatera.

Subjects and Method: This was an analytic observational study with a case control design and retrospective. This study was conducted in Langkat, North Sumatera from March to July 2017. A sample of 88 people, consisting 44 cases of malaria and 44 controls was selected by purposive sampling. The dependent variable was malaria. The independent variables were age, gender, mosquito net, mosquito repellent, hanging out habit, environmental hygiene, temperature, water puddle. The data were collected by questionnaire and analyzed by a multiple logistic regression.

Results: Factors that increased the incidence of malaria were environmental hygiene $(\mathrm{OR}=3.85 ; 95 \% \mathrm{CI}=1.57$ to $9.43 ; \mathrm{p}=0.003)$, temperature $(\mathrm{OR}=2.83$; $95 \% \mathrm{CI}=1.13$ to $7.12 ; \mathrm{p}=0.025)$, waterlogging $(\mathrm{OR}=3.06 ; 95 \% \mathrm{CI}=1.28$ to 7.30 ; $\mathrm{p}=0.011)$. Factor that decreased the incidence of malaria was the use of mosquito repellent $(\mathrm{OR}=0.39 ; 95 \% \mathrm{CI}=0.17$ to $0.94 ; \mathrm{p}=0.033)$. However, age $(\mathrm{OR}=1.45$; $95 \% \mathrm{CI}=0.63$ to $3.36 ; \mathrm{p}=0.392)$, $\operatorname{sex}(\mathrm{OR}=1.09 ; 95 \% \mathrm{CI}=0.47$ to $2.53 ; \mathrm{p}=0.831)$, the use of mosquito net $(\mathrm{OR}=1.96 ; 95 \% \mathrm{CI}=0.62$ to $3.91 ; \mathrm{p}=0.350)$, and hanging out habit $(\mathrm{OR}=2.29 ; 95 \% \mathrm{CI}=0.98$ to $5.39 ; \mathrm{p}=0.055)$ did not show significant effect on the incidence of malaria.

Conclusion: Factors influencing the incidence of malaria are environmental hygiene, temperature, waterlogging, and the use of mosquito.
\end{abstract}

Keywords: determinants, malaria

\section{Correspondence:}

Rahmadani Sitepu. Department of Public Health, Faculty of Medicine, Universitas Islam Sumatera Utara, Jl. STM No.77 Medan.

Email: drrsitepu@gmail.com. Mobile: 081375012756. 